University of Nebraska - Lincoln

DigitalCommons@University of Nebraska - Lincoln

Nebraska Game and Parks Commission -- Staff

Research Publications

Nebraska Game and Parks Commission

January 1981

\title{
A Generalized Inland Fishery Simulator for Management Biologists
}

Melvin W. Taylor

Nebraska Game and Parks Commission

Follow this and additional works at: https://digitalcommons.unl.edu/nebgamestaff

Part of the Environmental Sciences Commons

Taylor, Melvin W., "A Generalized Inland Fishery Simulator for Management Biologists" (1981). Nebraska Game and Parks Commission -- Staff Research Publications. 33.

https://digitalcommons.unl.edu/nebgamestaff/33

This Article is brought to you for free and open access by the Nebraska Game and Parks Commission at DigitalCommons@University of Nebraska - Lincoln. It has been accepted for inclusion in Nebraska Game and Parks Commission -- Staff Research Publications by an authorized administrator of DigitalCommons@University of Nebraska - Lincoln. 


\title{
A Generalized Inland Fishery Simulator for Management Biologists
}

\author{
Melvin W. TAYLOR ${ }^{1}$ \\ Nebraska Game and Parks Commission \\ P.O. Box 30370, Lincoln, Nebraska 68503
}

\begin{abstract}
Presently available fishery models are either too simplified or too complicated to be useful to inland fishery managers. This research was directed toward developing a simplified but realistic computerized simulator useful to fishery managers. The model developed is basically an ageclass structured simulator with features built in to allow easy but effective use by fishery managers. It includes provisions for input of all important parameters plus provisions for densitydependent relationships where applicable. Examples of model use are given for a put-and-take rainbow trout (Salmo gairdneri) fishery and a self-sustaining walleye (Stizostedion vitreum) population.
\end{abstract}

Effective management of fish populations requires synthesis and interpretation of large quantities of data. Attempts to synthesize existing data into an interpretable form has led to the development of mathematical models designed to simulate fish populations. The goal of most models is to develop an understanding of a fishery that allows for more effective management. The dynamic-pool model (Beverton and Holt 1957) and the surplus-yield model (Schaefer 1954) provide the basis for most modeling attempts. These models have been thoroughly analyzed and many variations of the basic models were developed (Tester 1953; Paulik 1969; Schaefer 1968; Tautz et al. 1969; Pella and Tomlinson 1969; Fox 1970; Francis 1974; Youngs 1976; Schnute 1977; DeAngelis et al. 1977; Walter 1978). These models have been used with some success on marine commercial species, but have been less than successful when applied to inland fisheries.

Watt (1956) discussed basic fishery models and presented a model of his own which appears to be more realistic for inland populations. However, considerable data and mathematical expertise are required to use it. Zuboy and Lackey (1975) discussed fishery models and presented a model for a multi-species centrarchid population. Paulik (1969) also discussed various models and their attributes. Walters (1969) developed a generalized computer sim-

\footnotetext{
${ }^{1}$ Present address: Federal Land Bank, Ord, Nebraska 68862 .
}

ulator which probably is close to being suited for inland sport fishery work, but it requires the fitting of growth curves, uses instantaneous rates, and does not provide for simple manipulation of size limits, seasons, and within-year periods. Few if any simulations now available contain density functions and stochastic processes for important population parameters.

Simpler models, mathematically speaking, have been developed by Carlander (1958), Tyler (1974), Orth (1975), and Pollard (1976). Many investigators have also used simple, uncomputerized models to assess fishery problems (Patriarche 1968; Latta 1971, 1974; Schneider 1973; Gulish 1975). Since these investigators performed calculations manually, their models were necessarily oversimplified. Tyler (1974) and Orth (1975) used computer simulation with their models, but Orth's is a single-species, largemouth bass (Micropterus salmoides) model and Tyler's is not generalized and properly equipped to handle many inland fishery problems.

With so many models available for many years, it would seem that their use would be more widespread among state fishery agencies, the primary management entities for inland fisheries. This is not true and is likely due to several factors:

1. The theoretical basis of many models is too complicated for the average biologist to understand. Even a field biologist with an above-average exposure to modeling and mathematics cannot be expected to utilize 
most of the models presented in the literature.

2. The models are not suitable for inland fisheries due to the data required, the model form and assumptions, or model output. Data requirements may exclude inland fisheries or the required form may need considerable data manipulation prior to modeling. The mechanisms of the model are often inappropriate for an inland sport fishery.

3. The models are not generalized enough to be used with a variety of species or waters. Most of the models are marine-oriented or species-specific. Generalized models available for inland fisheries have other deficiencies which detract from their usefulness.

4. The models do not include realistic features such as random environmental factors and density-dependent functions. Although many models are mathematically complicated, their realism is suspect due to omission of these factors. Inclusion of these factors is important for the sake of realism even if in a very simple form.

5. Models that are mathematically simple have not been computerized in a format usable by most management agencies. The available computerized models are not directed toward the management of inland fisheries. Several suitable modeling techniques are available but have not been computerized.

This research was an attempt to bridge the gap between presently available models, modeling techniques, and the needs of the field biologist, who should be the primary user of the model. The objective of this study was to develop a computerized simulator with the following characteristics for use by inland freshwater fish management biologists:

1. The model must be mathematically simple. Basic construction must be difference equations with some simple functional relationships. No calculus or instantaneous rates were to be used.

2. The model must be generalized to handle any species and a wide variety of simulation problems such as size limits, seasons, forage introductions, and supplemental stocking.

3. The model must use data commonly collected from freshwater fisheries, preferably in the form normally collected without excessive manipulation. Length-frequency,
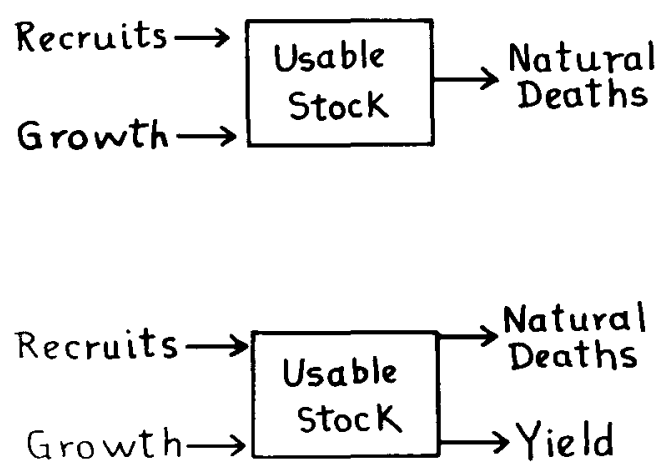

FIGURE 1.-Diagram of the dynamics of a fish stock (fish of usable sizes), when there is no fishing and when there is a fishery. (From Ricker 1975)

age-growth, length-weight, mortality, and recruitment were to be the basic inputs.

4. It must provide enough mechanisms to allow realistic results. This necessarily means that density mechanisms should be included.

5. It must be flexible enough to handle simple to complex problems in an equally efficient manner depending upon user needs.

6. Implementation must be simple enough to encourage use.

\section{Model Development}

The simulator developed used information from several existing models (Walters 1969; Tyler 1974; Orth 1975; Pollard 1976) plus several new techniques. The basic model uses age classes and difference equations. Similar techniques have been used very successfully for modelling big game (Gross 1970), mallards (Walters et al. 1974), and pheasants (Taylor 1978). Carlander (1958) and Orth (1975) also used this approach.

The model is developed on the basis of Fig. 1 (Ricker 1975). A population $F_{n}$, after one time period, will gain in numbers from recruitment $(r)$, gain in biomass from growth $(g)$ and lose numbers to natural $(v)$ and fishing $(u)$ mortality. This can be represented by:

$$
\mathrm{F}_{\mathrm{n}+1}=\mathrm{F}_{\mathrm{n}}-\mathrm{F}_{\mathrm{n}}(u+v)+\mathbf{f}(g)+r
$$

where:

$F_{n+1}=$ numerical population size at the end of one time period, usually one year 


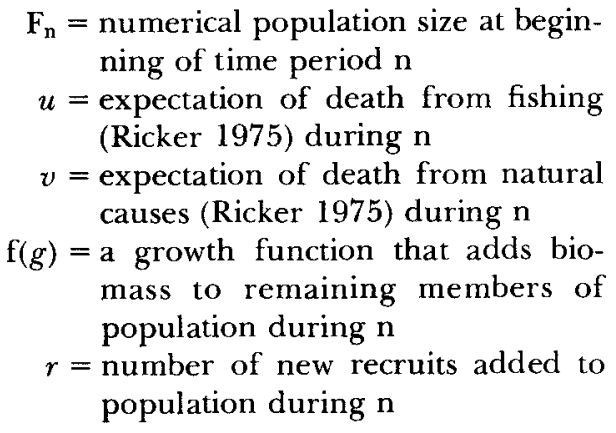

In fishery systems, the basic population parameters $(u, v, r, g)$ are not necessarily equal for all age classes. To be more realistic, a model must include age-specific characteristics. This can be accomplished by making the calculations for each age class separately using age-specific rates as:

$$
\mathbf{F}_{\mathrm{n}+\mathcal{H}_{i+1}}=\mathbf{F}_{\mathrm{n} i}-\mathbf{F}_{\mathrm{n} i}\left(u_{i}+v_{i}\right)+\mathbf{f}\left(g_{i}\right)+r
$$

where $i$ refers to age class, $r=0$ when $i \neq 1$. It follows that the total population at time $\mathrm{n}+\mathrm{l}$ is:

$$
\mathrm{F}_{\mathbf{n}+\mathbf{1}}=\sum_{i=1}^{\mathrm{NAGE}}\left[\mathrm{F}_{\mathbf{n}+\mathbf{1}, i}-\mathrm{F}_{\mathrm{n}+1, i}\left(u_{i}+v_{i}\right)+\mathrm{f}\left(g_{i}\right)\right]+r
$$

where $\mathrm{NAGE}=$ number of age classes in the population.

Likewise, sex of the fish often alters the same parameters. To include sexual differences, sexes can be handled separately as:

$$
\mathbf{F}_{\mathbf{n}+\mathbf{1}, i+1, k}=\mathbf{F}_{\mathbf{n} i k}-\mathbf{F}_{\mathbf{n} i k}\left(u_{i k}+v_{i k}\right)+\mathrm{f}\left(g_{i k}\right)+r_{k}
$$

where $k$ refers to sex. The total population $\mathbf{F}_{\mathbf{n}+1}$ is then:

$$
\begin{gathered}
\mathrm{F}_{\mathrm{n}+1}=\sum_{k=1}^{2} \sum_{i=1}^{\mathrm{NAGE}}\left\{\left[\mathrm{F}_{\mathrm{n} i k}-\mathrm{F}_{\mathrm{n} i k}\left(u_{i k}+v_{i k}\right)\right.\right. \\
\left.\left.-\mathrm{f}\left(g_{i k}\right)\right]+r_{k}\right\}
\end{gathered}
$$

In most fish populations, the critical factors of mortality, recruitment and growth do not occur at a constant, linear rate throughout the year (Ricker 1975). However, many models make this assumption or a similar simplifying assumption. In some populations this can cause significant error in simulation results. Ricker (1975) suggested running the simulation on shorter time periods, a reasonable approach if the simulator is constructed to do so easily. Provisions were made in the present model to include up to 12 periods within the year while maintaining the year as the basic simulation period. The number of periods per year and their length is user-specified to fit the population being modelled. Period-specific rates must be provided. This allows the use of several linear segments to simulate a non-linear factor. By the addition of period-specific capability and adding over periods:

$$
\begin{gathered}
\mathrm{F}_{\mathrm{n}+1}=\sum_{k=1}^{2} \sum_{j=1}^{\text {NPER NAGE }} \sum_{i=1}^{N}\left\langle\left\{\left[\mathrm{~F}_{\mathrm{n} i k j}-\mathrm{F}_{i k j}\left(u_{i k j}+v_{i k j}\right)\right.\right.\right. \\
\left.\left.\left.+\mathrm{f}\left(g_{i k j}\right)\right]\right\}+r_{k}\right\rangle
\end{gathered}
$$

where NPER is the number of periods in the year.

This model is simple enough to handle cases where no age, sex, or period-specific factors are desired, but flexible enough to handle a rather complex, more realistic system if the investigator desires. The simulation operates by repeatedly solving the equation for the next year's population. The model is coded in Fortran IV, G Level, for an IBM 370/158. Optional features allow use of the program on batch mode systems or on the IBM Conversational Monitor System (CMS). A program listing that contains user documentation, program decks, and complete outputs for all examples presented in this paper is available from the author.

Several density-dependent relationships described above require user-supplied coefficients. These can be determined from empirical data using regression analysis where suitable data are available. In other instances, coefficients can be estimated from knowledge of the population and then adjusted where needed when fine-tuning the simulation.

Each of the basic parameters used in the model and their characteristics are discussed below.

\section{Growth}

Average growth for the population is calculated from a vector of lengths-at-age (millimeters) such as is normally back-calculated from a sample of aged fish. The model assumes the given lengths to be averages for the population being modelled. They are used to calculate relative growth as a function of length. All fish in the given age class are assumed to be the same length. Weight (grams) at length is calculated from a weight-length regression for which the user supplies the coefficients. If the multiple period-per-year option is used, the user must 


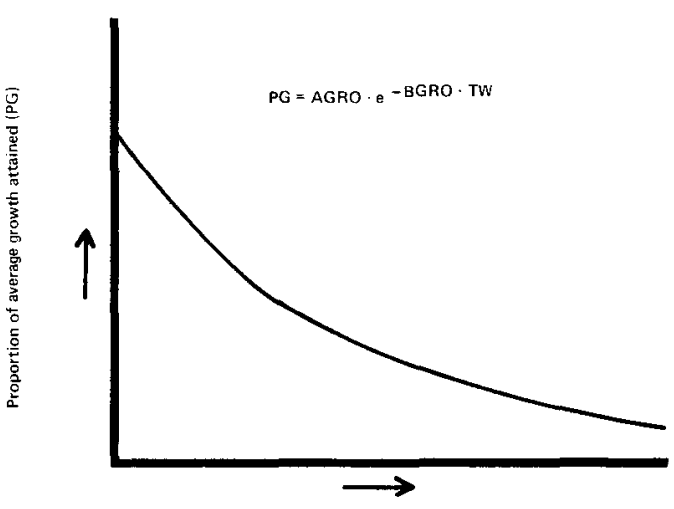

Biomass (kg) of simulated population (TW)

FIGURE 2.-Density-dependent relationship between population biomass and proportion of average growth attained at that biomass.

specify the proportion of total annual growth that occurs in each period. Within a period, growth is assumed to occur in a linear fashion. If this assumption is invalid, the interval should be further divided.

It is common knowledge that fish growth varies as a function of fish density and other environmental variables such as interspecific competition, habitat changes, water temperature, and others. In the model, provisions are made for the user to supply a density-dependent growth function, if desired. The model provides a function of the form described by Tadeusz and LeCren (1967) and Tyler (1974). It assumes that growth is a decaying exponential function of biomass present (Fig. 2):

where: $\quad \begin{aligned} \mathrm{PG}= & \mathrm{AGRO} \cdot e^{-\mathrm{BGRO} \cdot \mathrm{TW}} \\ \mathrm{PG}= & \text { proportion of normal } \\ & \text { growth achieved with given } \\ & \text { biomass; should equal one } \\ & \text { at average population } \\ & \text { density. } \\ \mathrm{TW}= & \text { total biomass of population } \\ & \text { in } \mathrm{kg} .\end{aligned}$

AGRO, BGRO = user-supplied coefficients.

(If $\mathrm{AGRO}=1$ and $\mathrm{BGRO}=0$, no density function is applied.)

The user can also provide his own density function by replacing some FORTRAN statements as long as the end result is a factor that represents the proportion of normal growth (PG) which will be attained under the density con-

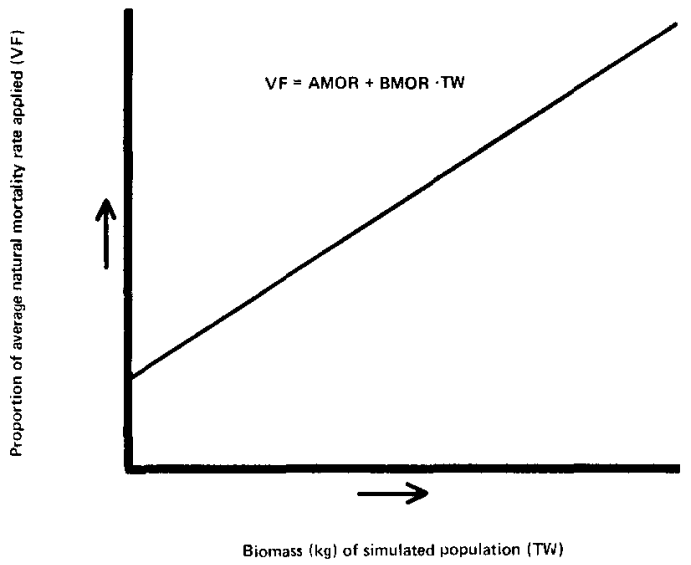

FIGURE 3.-Density-dependent relationship between the biomass of the simulated population and the proportion of the average expectation of natural death that is applied.

ditions present. In most populations, growth also varies as a function of several other, often unmeasurable factors such as variations in food supply, interspecific competition, and weather. However, it is often possible to determine the average growth and the annual variability associated with it. This estimate of variability can be used to supply the standard deviation for a random-number generator which provides a stochastic number with a mean of one and a standard deviation supplied by the user. This value is multiplied by $P G$ to create realistic, random fluctuations in growth, the magnitude of which is controlled by the user-supplied standard deviation. In the absence of specific data, this approach is an appropriate way to include random effects of unmeasured factors and produce realistic results.

\section{Natural mortality}

Natural mortality $(v)$ is represented in the model by expectation of natural death (Ricker 1975), which is the proportion of a given population present at the beginning of the period that dies from natural causes during the period. This is the simplest and perhaps most realistic expression of natural mortality (Ricker 1975). Average natural mortality rates that occur under average density and environmental factors are specified by the user for each age class, sex and period that is desired in the model.

A density-dependent mortality function (Fig. 3 ) is provided in the form: 


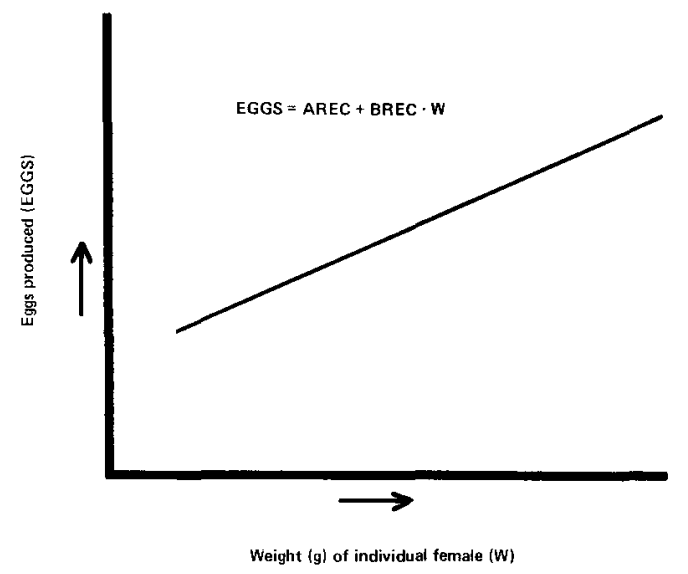

FigUrE 4.-Relationship between weight of individual females and number of eggs produced (valid only for mature females with weight $>0$ ).

$$
\mathrm{VF}=\mathrm{AMOR}+\mathrm{BMOR} \cdot \mathrm{TW}
$$

where: $\quad V F=$ proportion of average mortality rate to be applied with a given density. $\mathrm{VF}=1$ when density is at average level.

AMOR, BMOR $=$ user-supplied coefficients.

$\mathrm{AMOR}=1$ and $\mathrm{BMOR}=0$ when no density dependence is desired.

The user can, if desired, replace the function provided by minor program changes as long as the $\mathrm{VF}$ generated specifies the proportion of average natural mortality that is applied under existing density conditions.

A randomization process is applied to $\mathrm{VF}$ in a manner similar to that in the growth function. A random normal deviate with a mean of one and a user-supplied standard deviation is generated and used as a multiplier. The natural mortality applied is ultimately calculated as:

$$
\mathrm{VCAL}=\mathrm{VF} \cdot \mathrm{REAL} \cdot v
$$

where: $\mathrm{VCAL}=$ applied natural mortality.

REAL = normal random deviate with mean of one and user specified standard deviation.

This provides for variation in natural mortality with a magnitude specified by the user.

\section{Recruitment}

Recruits, whether vulnerable to the fishery or not, are assumed to enter the population at the

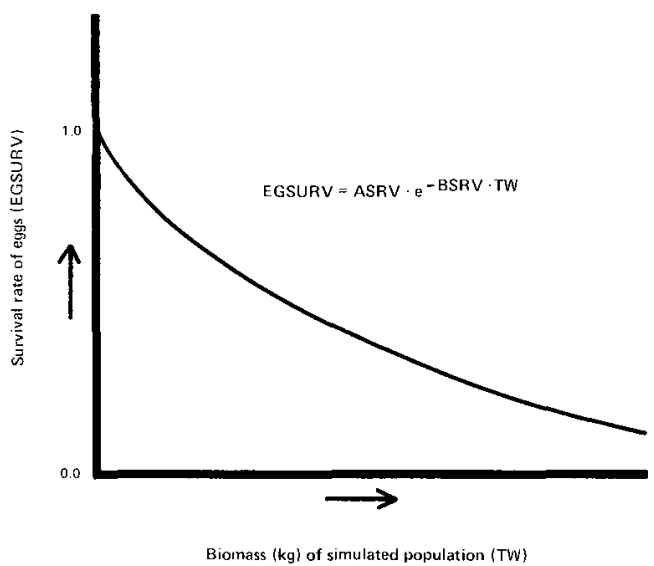

Figure 5.-Density-dependent relationship between the biomass of simulated population and the survival of eggs from spawning to start of next simulated year.

beginning of the first year after they are spawned. The number recruited is calculated from the number of eggs spawned and an associated survival to the beginning of the following year. The number of eggs available from each mature female is calculated from a fecundity-weight regression (Fig. 4) of the form:

$$
\mathrm{EGGS}=\mathrm{AREC}+\mathrm{BREC} \cdot \mathrm{W}
$$

where: $E G G S=$ number of eggs from female of weight $W$.

$W=$ weight of female in grams.

AREC, BREC $=$ user-supplied coefficients.

Other methods or functions for calculating eggs per female can also be used with minor program modifications. Total available eggs is found by summing the production of all mature females. Survival of the eggs is calculated from a density function and the application of a random factor. The model contains the density function (Fig. 5):

$$
\text { EGSURV }=A S R V \cdot \mathrm{e}^{-B S R V \cdot T W}
$$

where: $E G S U R V=$ proportion of total eggs surviving to beginning of next year.

ASRV, BSRV = user-supplied coefficients.

Other functions can be used by simple modification of the program. EGSURV is then multiplied by a random deviate with a standard deviation furnished by the user to obtain the ultimate survival rate. 
Provisions also are made for the user to include stocked recruits and their associated survival to the beginning of the next year which is added to the natural recruitment. Recruitment is then calculated from:

$$
\mathrm{R}=\mathrm{EGSURV} \cdot \mathrm{EGGS}+\mathrm{STOCK} \cdot \mathrm{STSURV}
$$

where: $\quad \mathrm{R}=$ total recruits to age 1 .

EGSURV = survival rate from eggs to beginning of next year.

STOCK $=$ number of young-of-the-year stocked.

STSURV = survival rate of stocked fish to January 1.

A sex ratio of $1: 1$ is assumed. The model has the capability to handle natural reproduction, supplemental stocking, maintenance stocking or any combination.

\section{The fishery}

Although generalized enough to handle nearly any type of fishery, the model is directed toward inland sport fisheries. The expectation of death due to fishing $(u)$ is a user-specified constant (age, sex and period specific). The specified rate is assumed to apply under conditions of no size limits, closed seasons, or other special regulations.

The model provides for a user-specified open season, one season per year. Opening and closing dates need not fall at the beginning of a period. When an opening or closing date falls within a period, the season is assumed to be open the entire period if more than half would have been open; closed for the whole period if less than half the period was specified to be open.

The length (millimeters) at which fish first become vulnerable to the angler can be specified (AMINSZ). If a fish attains this length in the middle of a period, the fish is assumed to be vulnerable for the entire period if its average length (length at start of period plus length at end divided by 2) during the period exceeds AMINSZ. If its average length is less than AMINSZ, it is not vulnerable at all during the period.

The model also provides for the application of four variations of length limits:

1) No limit

2) Slot limit, minimum-maximum length, fish outside range
TABLE 1.-Summary showing average characteristics of the walleye population in Lake McConaughy over 30 simulated years, no size limit. Values are on a basis of 100 hectares.

\begin{tabular}{lc}
\hline Average number of fish in population & 3,821 \\
Average population biomass (kg) & 1,126 \\
Average number harvested annually & 753 \\
Average annual yield $(\mathrm{kg})$ & 453 \\
$\begin{array}{l}\text { Average weight of fish in creel }(\mathrm{kg}) \\
\text { Average number of fish caught }\end{array}$ & 0.604 \\
$\quad$ and released annually & 142 \\
\hline
\end{tabular}

3) Minimum length limit

4) Window limit, minimum-maximum length, fish inside range

In instances where fish grow into or out of a legal size during a modelling period, the fish is assumed to be of legal size for the entire period if its average length during the period was of legal size.

Total catch is obtained by multiplying the exploitation rate $(u)$ by the population of legalsize fish available in the open season. Yield $(\mathrm{kg})$ is calculated by summing, over age classes, the number in the catch and multiplying by the average weight of individual fish in the period. The average weight is assumed to be the mean of the weights at the beginning and end of the period. The number of fish caught and released is calculated by multiplying $u$ by the number of fish of size vulnerable to anglers but sublegal, out of season or unacceptable to anglers. Total catch plus number caught and released would equal catch without special regulations. A user-supplied hooking mortality is applied to all fish caught and released.

\section{Model input and output}

The minimum model input consists of:

1) Basic control parameters such as number of years to run, year at start, number of age classes, and other easily supplied parameters.

2) Initial age structure or the number in each age class at the start of simulation.

3) The average length at age for the population.

4) Weight-length regression coefficients.

5) Natural and fishing mortality rates.

Additional input can be provided as the complexity of the system increases. These inputs 
TABLE 2.-Simulation results for a rainbow trout fishery with no density functions, except a variable stocking rate.

\begin{tabular}{cccccc}
\hline $\begin{array}{c}\text { Number } \\
\text { stocked }\end{array}$ & $\begin{array}{c}\text { Population } \\
\text { size }\end{array}$ & $\begin{array}{c}\text { Population } \\
\text { biomass }(\mathrm{kg})\end{array}$ & $\begin{array}{c}\text { Catch in } \\
\text { numbers }\end{array}$ & $\begin{array}{c}\text { Yield } \\
\text { (kg) }\end{array}$ & $\begin{array}{c}\text { Average weight } \\
\text { of fish in } \\
\text { catch (kg) }\end{array}$ \\
\hline 10,000 & 8,560 & 1,309 & 4,280 & 1,894 & 0.428 \\
30,000 & 25,679 & 3,926 & 12,839 & 5,683 & 0.428 \\
50,000 & 42,798 & 6,544 & 21,399 & 9,471 & 0.428 \\
\hline
\end{tabular}

include the number of simulation periods per year, length limits, seasons, density coefficients, stocking rates, growth patterns, starting dates of a period, age, sex and period-specific rates for growth, and fishing and natural mortality.

Model output consists of a listing of input data and detailed parameter summaries by age, sex and period. Optional plots are available for the key population parameters of population size, biomass, recruitment, natural mortality, and various parameters of the fishery. For conversational computer systems, output tables and plots are available in 22 line by 80 column segments for viewing on a cathode-ray tube. A summary table (Table 1 ) is generated at the end of the simulation showing long-term averages of critical population parameters.

\section{Application of the Model}

All known information about a given population is assembled and used to develop the required input for the model. Estimates of unknown parameters can be used to make the initial run. Successive simulations are then made while adjusting appropriate parameters to produce a model that mimics the real population. This process may seem crude as there is no statistical procedure involved in obtaining a "best fit," but it works very well. The procedure has proven to be very effective in modelling big game herds (Gross, personal communication). When the model reflects the real population as nearly as possible, experimental simulations then can be made to determine the effect of various perturbations on the fish population.

Two examples are presented to illustrate the modeling procedure and show how the model can be useful to manage a fishery. The first example deals with a put-and-take rainbow trout (Salmo gairdneri) fishery, and the second with a rather complicated, self-sustaining walleye (Stizostedion vitreum) fishery.

\section{Rainbow Trout Population}

As a simple example, a lake of 100 hectares was to be stocked with rainbow trout fingerlings. Stocking was to take place in late summer with fish at $50 \mathrm{~mm}$ total length. The objective of modelling the population was to determine the yields, in both number and size, resulting from various stocking levels. A natural mortality rate of 0.40 and an exploitation rate of 0.50 was applied to all ages and both sexes. Growth rates were taken from the following mean length-at-age data:

Length (mm) at age

I II III IV $\mathrm{V}$ VI VII VIII IX $\mathrm{X}$ XI XII XIIIXIV XV

200400500550600625630635640645650655660665670

A weight-length equation of $\mathrm{W}=$ $0.0000215 \mathrm{~L}^{2.88}$, one period per year, and no density functions were used. No age- and sexspecific rates were used. Fish were assumed to

TABLE 3.-Results of a rainbow trout simulation with density-dependent growth included.

\begin{tabular}{cccccc}
\hline $\begin{array}{c}\text { Number } \\
\text { stocked }\end{array}$ & $\begin{array}{c}\text { Population } \\
\text { size }\end{array}$ & $\begin{array}{c}\text { Population } \\
\text { biomass }(\mathrm{kg})\end{array}$ & $\begin{array}{c}\text { Catch in } \\
\text { numbers }\end{array}$ & $\begin{array}{c}\text { Yield } \\
(\mathrm{kg})\end{array}$ & $\begin{array}{c}\text { Average weight } \\
\text { of fish in } \\
\text { catch (kg) }\end{array}$ \\
\hline 10,000 & 8,560 & 1,309 & 4,280 & 1,894 & 0.428 \\
20,000 & 17,119 & 2,617 & 8,560 & 3,789 & 0.428 \\
30,000 & 25,679 & 3,730 & 12,839 & 5,459 & 0.411 \\
40,000 & 34,239 & 2,706 & 17,119 & 4,369 & 0.247 \\
50,000 & 61,975 & 3,475 & 12,988 & 3,232 & 0.246 \\
\hline
\end{tabular}




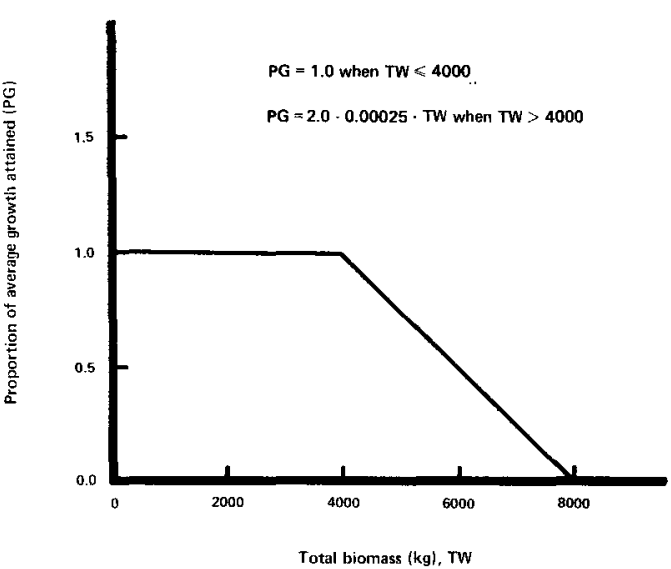

FIGURE 6.-Density-dependent growth relationship for hypothetical rainbow trout population.

enter the fishery at a total length of $200 \mathrm{~mm}$. A survival rate of 0.80 was used from stocking date to 1 January following stocking. A series of simulations were made from which yield, number and size of fish harvested were recorded for stocking rates of $10,000-50,000$ fish per year (Table 2).

From the results, it was apparent that the model predicted a linearly increasing yield with increased stocking. When the population was well below carrying capacity, this relationship

TABLE 4.--Length (millimeters) and age frequency of 124 walleyes, Lake McConaughy, 1971.

\begin{tabular}{|c|c|c|c|c|c|}
\hline \multicolumn{3}{|c|}{ Length frequency } & \multicolumn{3}{|c|}{ Age frequency } \\
\hline $\begin{array}{l}\text { Length } \\
\text { group }\end{array}$ & $\begin{array}{c}\text { Num- } \\
\text { ber }\end{array}$ & Percent & Age & $\begin{array}{c}\text { Num- } \\
\text { ber }\end{array}$ & Percent \\
\hline $175-199$ & 3 & 2.4 & $0+$ & 4 & 3.2 \\
\hline $200-224$ & 1 & 0.8 & $0+$ & & \\
\hline $\begin{array}{l}225-249 \\
250-274\end{array}$ & $\begin{array}{r}9 \\
37\end{array}$ & $\begin{array}{r}7.3 \\
30.0\end{array}$ & $\begin{array}{l}\text { I+ } \\
\text { I+ }\end{array}$ & 56 & 45.5 \\
\hline $\begin{array}{l}275-299 \\
300-324\end{array}$ & $\begin{array}{l}9 \\
2\end{array}$ & $\begin{array}{l}7.3 \\
1.6\end{array}$ & $\begin{array}{l}\mathrm{I}+ \\
\mathrm{I}+, \mathrm{II}+\end{array}$ & & \\
\hline $\begin{array}{l}325-349 \\
350-374 \\
375-399\end{array}$ & $\begin{array}{r}7 \\
20 \\
17\end{array}$ & $\begin{array}{r}5.7 \\
16.3 \\
13.8\end{array}$ & $\begin{array}{l}\mathrm{II+} \\
\mathrm{II}+ \\
\mathrm{II}+\end{array}$ & 57 & 46.3 \\
\hline $\begin{array}{l}400-424 \\
425-449\end{array}$ & $\begin{array}{l}7 \\
5\end{array}$ & $\begin{array}{l}5.7 \\
4.1\end{array}$ & $\begin{array}{l}\mathrm{II}+ \\
\mathrm{II}+\end{array}$ & & \\
\hline $\begin{array}{l}450-474 \\
475-499\end{array}$ & $\begin{array}{l}1 \\
2\end{array}$ & $\begin{array}{l}0.8 \\
1.6\end{array}$ & $\begin{array}{r}\text { III }+ \text { or } \\
\text { older }\end{array}$ & 6 & 4.9 \\
\hline $\begin{array}{l}500-524 \\
525-549\end{array}$ & $\begin{array}{l}0 \\
3\end{array}$ & 2.4 & & & \\
\hline
\end{tabular}

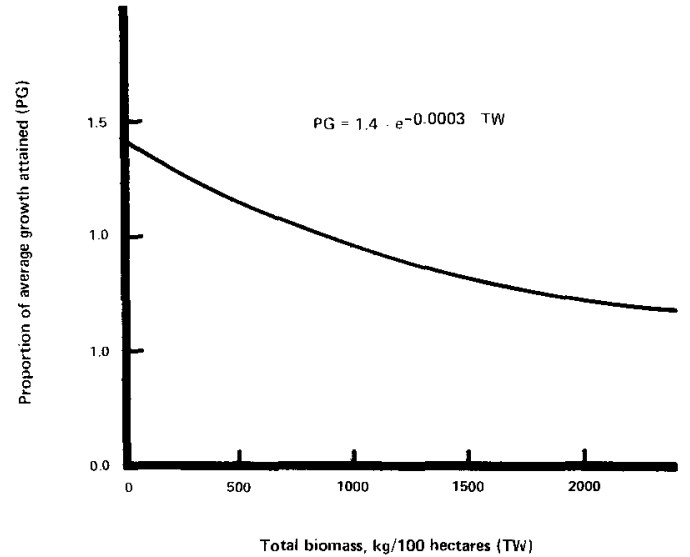

FIGURE 7.-Density-dependent growth relationship used for simulation of typical western Nebraska walleye population.

was not unreasonable. However, as the stocking rate approached or exceeded carrying capacity, growth would decrease and/or mortality would increase. To illustrate how the simulation could be made more realistic when stocking exceeded carrying capacity, a density function for growth was added. It was assumed that growth would remain normal until the biomass reached $40 \mathrm{~kg} /$ hectare. Then growth would decrease linearly until no growth would be achieved at $80 \mathrm{~kg} /$ hectare (Fig. 6). With this function in place, the simulated results were much more realistic. Varying the stocking rate resulted in output that could be used to optimize the stocking rate to achieve maximum yield, maximize number of fish harvested, and maximize the size harvested or some combination thereof (Table 3). This is a rather simple example, but it illustrates a use of the model on simple problems that would be difficult to solve manually.

\section{Walleye Population}

This example details the application of the model to an actual situation that occurred in Nebraska. In 1979, considerable pressure was received from western Nebraska sportsmen to implement a minimum length limit on walleyes. Some simple models had been used in previous years to evaluate the possible effects of various minimum length limits on walleye populations, but these models lacked the realism needed to make sound decisions. In this instance, an effort was made to produce a more realistic mod- 
TABLE 5._Mean length (millimeters) at age for walleye in Lake McConaughy, 1964.

\begin{tabular}{ccccccccccc}
\hline \multicolumn{10}{c}{} & \multicolumn{1}{c}{ Length at age } \\
\hline I & II & III & IV & V & VI & VII & VIII & IX & X \\
\hline 200 & 360 & 440 & 500 & 560 & 620 & 675 & 730 & 770 & 780 \\
\hline
\end{tabular}

el of a western Nebraska walleye population. Much of the data used was from Lake McConaughy, although the primary population characteristics are very similar for most waters in that part of the state.

To construct the model, as much general information as possible was gathered on walleyes, and on western Nebraska and Lake McConaughy walleye, specifically. Available information included length and age frequency from sampling and creel checks (Table 4), growth, various creel statistics, and estimates of survival rates. Based on knowledge of the patterns of growth and exploitation, the year was divided into four periods for simulation purposes: 1 January-31 March; 1 April-15 June; 16 June-31 October; and 1 November-31 December.

\section{Growth}

The growth of walleyes has been found to vary little from the long-term average of Lake McConaughy walleyes (Table 5). Therefore, a low standard deviation of 0.05 was used in the growth function to simulate random fluctuations in growth. A density-dependent growth function was applied (Fig. 7). The density function was developed solely on the basis of familiarity with the population and data associated with it. No appropriate density-related growth data were available.

The following length-weight equation was obtained from empirical data:

$$
\mathrm{W}=0.0000027 \mathrm{~L}^{3.19}
$$

Field observations indicated $90 \%$ of the growth occurred in 16 June-31 October; $10 \%$ in November and December.

\section{Natural mortality}

An estimate of total annual mortality of 0.55 (Table 6) was calculated from tag returns using Model 1 of Brownie et al. (1978). Little was known about how this value should be divided between natural and fishing mortality or between sexes and age classes. Initial guesses were made for each period and age class. No specific sex differences were included. These rates were adjusted where deemed necessary once the modeling process began. Eventually, the rates shown in Table 7 were derived and used in the model as averages. A density-dependent natural mortality was applied according to the relationship in Fig. 8. A standard deviation of 0.1 was used in the random-number generator to simulate minimal fluctuations in natural mortality resulting from unknown factors.

\section{Fishing mortality}

An intensive creel census was done on Lake McConaughy in 1977-1978. From this census, the harvest of walleye was estimated to be 3.42 $\mathrm{kg} /$ hectare consisting of 6.25 fish per hectare that weighed $0.547 \mathrm{~kg}$ on the average. Ninety percent of the harvest occurred primarily in the spring (1 April-15 June) with some in each of

TABLE 6.-Angler returns of tagged walleye, Lake McConaughy. Survival estimates from Brownie et al. (1978).

\begin{tabular}{|c|c|c|c|c|c|c|c|c|c|}
\hline \multirow{2}{*}{$\begin{array}{l}\text { Year } \\
\text { tagged }\end{array}$} & \multirow{2}{*}{$\begin{array}{l}\text { Number } \\
\text { tagged }\end{array}$} & \multicolumn{8}{|c|}{ Number caught and released } \\
\hline & & Year & 1961 & 1962 & 1963 & 1964 & 1965 & 1966 & 1967 \\
\hline 1961 & 305 & & 26 & 16 & 2 & 3 & 1 & 1 & 0 \\
\hline 1962 & 479 & & & 92 & 13 & 11 & 9 & 6 & 0 \\
\hline 1963 & 420 & & & & 29 & 26 & 14 & 3 & 0 \\
\hline 1964 & 338 & & & & & 41 & 10 & 3 & 1 \\
\hline 1965 & 379 & & & & & & 44 & 11 & 2 \\
\hline
\end{tabular}


TABLE 7.-Natural mortality rates (v) used in a walleye simulation. No sex-specific differences were included.

\begin{tabular}{lcc}
\hline & \multicolumn{2}{c}{ Age class } \\
\cline { 2 - 3 } \multicolumn{1}{c}{ Period } & I & II-X \\
\hline 1 January-31 March & 0.10 & 0.05 \\
1 April-15 June & 0.15 & 0.10 \\
16 June-31 October & 0.15 & 0.10 \\
1 November-31 December & 0.10 & 0.05 \\
\hline
\end{tabular}

the other three periods. Little was known of the standing crop available from which this harvest was taken. Consequently, exploitation rates were estimated initially and adjusted to gain agreement between simulated and observed characteristics. Average rates used in the final simulation are shown in Table 8 . No sex-specific differences were used. A hooking mortality of 0.10 was assumed for all fish caught and released.

\section{Recruitment}

A fecundity equation was derived by averaging two equations from Wolfert (1969). This equation was used to determine the number of eggs available from the standing stock:

$$
\mathrm{EGGS}=16.6 \mathrm{~W}^{1.19}
$$

where: EGGS $=$ the number of eggs produced. $W=$ weight of female in grams.

Survival of young was subjected to a densitydependent function (Fig. 9). Since little fluctuation was noted in annual recruitment, a low standard deviation of 0.1 was used in the stochastic function. Parameters were adjusted as needed to obtain realistic recruitment.

\section{Simulation Results}

An estimate of population density of $10 \mathrm{~kg} /$ hectare was made and divided into age groups

TABLE 8.-Exploitation rates (u) used in a walleye simulation. No sex-specific rates were used.

\begin{tabular}{cllll}
\hline & \multicolumn{4}{c}{ Age class } \\
\cline { 2 - 5 } \multicolumn{1}{c}{ Period } & \multicolumn{1}{c}{ I } & \multicolumn{1}{c}{ II } & III & IV-X \\
\hline 1 January-31 March & 0.0 & 0.0 & 0.0 & 0.0 \\
1 A pril-15 June & 0.10 & 0.45 & 0.35 & 0.25 \\
16 June-31 October & 0.10 & 0.15 & 0.10 & 0.10 \\
1 November-31 December & 0.05 & 0.05 & 0.05 & 0.05 \\
\hline
\end{tabular}

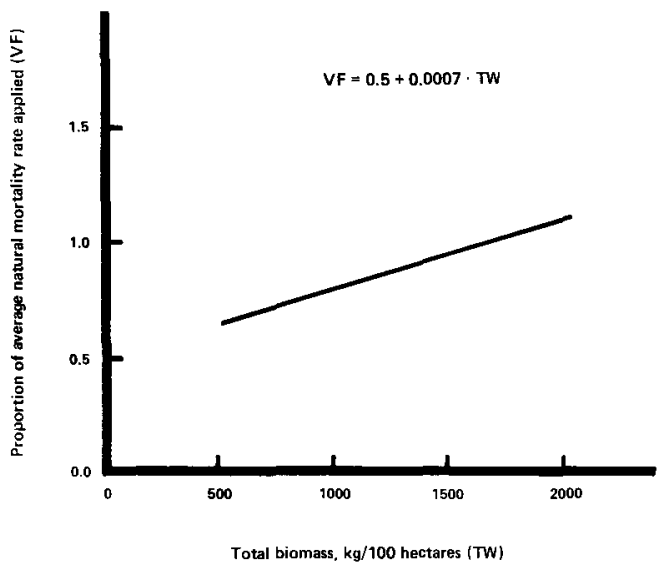

Figure 8.-Density-dependent relationship between natural mortality rate and total biomass used in simulation of typical western Nebraska walleye population, $500 \leqslant$ $T W \leqslant 2,000$.

to provide the initial population structure. All simulations were made on the basis of a lake of 100 hectares to keep numbers in the range that could be handled by the simulator. Successive simulations were made while adjusting appropriate parameters to provide a realistic representation of the population. The closeness of fit was judged from comparing actual to simulated data. Final simulation results for a typical year and long-term averages are shown in Tables 9 and 10 , respectively. At this point, the model was thoroughly tested to gain a feel for its re-

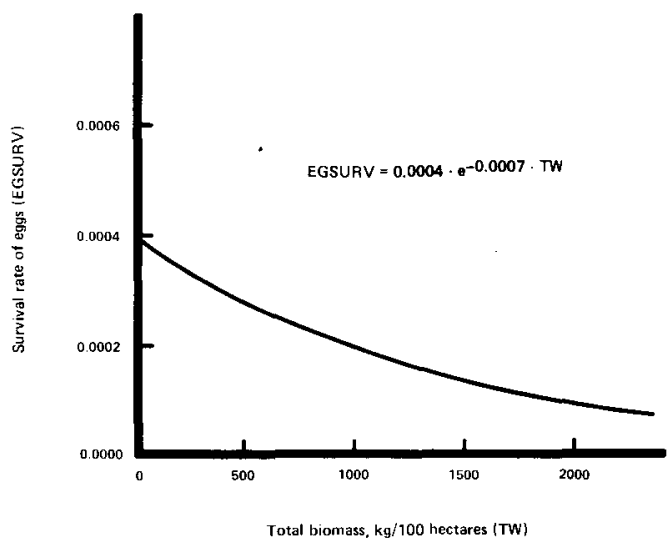

FIGURE 9.-Density-dependent relationship of juvenile survival and total biomass present for simulation of typir: western Nebraska walleye population. 
TABLE 9.-Results (per 100 hectares) of a typical simulated year for Lake McConaughy walleye, with no size limit.

\begin{tabular}{|c|c|c|c|c|c|c|c|c|}
\hline \multirow[b]{2}{*}{ Year 1984} & \multirow[b]{2}{*}{ Total } & \multicolumn{7}{|c|}{ Age } \\
\hline & & 1 & 2 & 3 & 4 & 5 & 6 & 7 \\
\hline $\begin{array}{l}\text { Number } \\
\text { Percentage }\end{array}$ & 4,379 & $\begin{array}{r}2,891 \\
66\end{array}$ & $\begin{array}{r}1,096 \\
25\end{array}$ & $\begin{array}{r}230 \\
5\end{array}$ & $\begin{array}{r}110 \\
3\end{array}$ & $\begin{array}{r}32 \\
1\end{array}$ & 8 & 5 \\
\hline \multicolumn{9}{|c|}{ Average length $(\mathrm{mm})$} \\
\hline $\begin{array}{l}\text { Males } \\
\text { Females }\end{array}$ & & $\begin{array}{l}214 \\
214\end{array}$ & $\begin{array}{l}373 \\
373\end{array}$ & $\begin{array}{l}453 \\
453\end{array}$ & $\begin{array}{l}514 \\
516\end{array}$ & $\begin{array}{l}561 \\
574\end{array}$ & $\begin{array}{l}608 \\
629\end{array}$ & $\begin{array}{l}649 \\
680\end{array}$ \\
\hline $\begin{array}{l}\text { Weight (kg) } \\
\text { Percentage }\end{array}$ & 1,114 & $\begin{array}{r}213 \\
19\end{array}$ & $\begin{array}{r}473 \\
42\end{array}$ & $\begin{array}{r}185 \\
17\end{array}$ & $\begin{array}{r}133 \\
12\end{array}$ & $\begin{array}{r}52 \\
5\end{array}$ & $\begin{array}{r}16 \\
1\end{array}$ & $\begin{array}{r}13 \\
1\end{array}$ \\
\hline $\begin{array}{l}\text { Expectation of } \\
\text { natural death }\end{array}$ & 0.44 & 0.54 & 0.25 & 0.28 & 0.28 & 0.29 & 0.29 & 0.28 \\
\hline Natural deaths & 1,943 & 1,554 & 279 & 63 & 31 & 9 & 2 & 1 \\
\hline Caught/kept & 761 & 77 & 542 & 91 & 35 & 10 & 2 & 2 \\
\hline Exploitation rate & 0.17 & 0.03 & 0.49 & 0.39 & 0.32 & 0.31 & 0.31 & 0.32 \\
\hline Caught/released & 194 & 194 & & & & & & \\
\hline Hooking loss & 19 & 19 & & & & & & \\
\hline Total yield $(\mathrm{kg})$ & 443 & 35 & $25 \mathrm{l}$ & 77 & 45 & 17 & 5 & 4 \\
\hline
\end{tabular}

\begin{tabular}{|c|c|c|c|c|c|c|c|c|}
\hline \multirow[b]{2}{*}{ Year 1984} & \multicolumn{8}{|c|}{ Age } \\
\hline & 8 & 9 & 10 & 11 & 12 & 13 & 14 & 15 \\
\hline $\begin{array}{l}\text { Number } \\
\text { Percentage }\end{array}$ & 5 & 2 & 1 & & & & & \\
\hline Average length (n & & & & & & & & \\
\hline $\begin{array}{l}\text { Males } \\
\text { Females }\end{array}$ & $\begin{array}{l}693 \\
734\end{array}$ & $\begin{array}{l}710 \\
772\end{array}$ & $\begin{array}{l}721 \\
779\end{array}$ & $\begin{array}{l}731 \\
791\end{array}$ & $\begin{array}{l}736 \\
796\end{array}$ & $\begin{array}{l}741 \\
801\end{array}$ & $\begin{array}{l}746 \\
806\end{array}$ & $\begin{array}{l}751 \\
811\end{array}$ \\
\hline $\begin{array}{l}\text { Weight (kg) } \\
\text { Percentage }\end{array}$ & $\begin{array}{r}18 \\
2\end{array}$ & $\begin{array}{l}9 \\
1\end{array}$ & 2 & & & & & \\
\hline $\begin{array}{l}\text { Expectation of } \\
\quad \text { natural death } \\
\text { Natural deaths } \\
\text { Caught } / \text { kept } \\
\text { Exploitation rate } \\
\text { Caught/released } \\
\text { Hooking loss } \\
\text { Total yield }(\mathrm{kg})\end{array}$ & $\begin{array}{l}0.28 \\
2 \\
2 \\
0.31\end{array}$ & $\begin{array}{l}0.29 \\
1 \\
1 \\
0.32\end{array}$ & 0.31 & & & & & \\
\hline
\end{tabular}

action to various perturbations to assure that it reacted realistically to given situations.

The ultimate objective of this process was to evaluate the effect of applying various mini-

TABLE 10.-Long-term averages for important variables of a simulated population of Lake McConaughy walleye over a 30-year period with no size limit. Values on a per 100-hectare basis.

\begin{tabular}{lr}
\hline Average number of fish in population & 3,821 \\
Average population biomass (kg) & 1,126 \\
Average number harvested annually & 753 \\
Average annual yield $(\mathrm{kg})$ & 453 \\
Average weight of fish in creel (kg) & 0.604 \\
Average number of fish caught & \\
$\quad$ and released annually & 142 \\
\hline
\end{tabular}

mum length limits. A series of simulations was made to determine the long-term effects of minimum length limits of $300,325,350,375$, 400,425 , and $450 \mathrm{~mm}$. From the results of these runs, Table 11 was constructed. This information was provided during the decisionmaking process to assess the effect of establishing a minimum length limit.

This example is a more complicated one showing how this model may be used to address a fishery problem. Actually, the simulator simply provides a framework upon which an investigator can build a model and experiment with a population. The complexity is controlled by the user. The framework is simple, flexible, and easy to use. The applications of such a sys- 
TABLE 11.-Estimated response of the Lake McConaughy walleye population to various length limits.

\begin{tabular}{|c|c|c|c|c|c|c|}
\hline \multirow{2}{*}{$\begin{array}{l}\text { Length } \\
\text { limit } \\
(\mathrm{mm})\end{array}$} & \multicolumn{2}{|c|}{ Population } & \multicolumn{3}{|c|}{ Angler harvest } & \multirow{2}{*}{$\begin{array}{l}\text { Number/ } \\
\text { hectare } \\
\text { caught and } \\
\text { released }\end{array}$} \\
\hline & $\begin{array}{c}\text { Number/ } \\
\text { hectare }\end{array}$ & $\begin{array}{c}\mathrm{kg} / \\
\text { hectare }\end{array}$ & $\begin{array}{c}\text { Number/ } \\
\text { hectare }\end{array}$ & $\begin{array}{c}\mathrm{kg} / \\
\text { hectare }\end{array}$ & $\mathrm{kg} /$ fish & \\
\hline None & 31.7 & 9.2 & 6.7 & 3.8 & 0.57 & 1.3 \\
\hline 300 & 31.7 & 9.2 & 6.7 & 3.8 & 0.57 & 1.3 \\
\hline 325 & 31.8 & 9.3 & 6.6 & 3.8 & 0.58 & 1.4 \\
\hline 350 & 33.4 & 9.9 & 6.2 & 3.8 & 0.63 & 2.3 \\
\hline 375 & 37.0 & 11.7 & 4.8 & 3.6 & 0.79 & 4.7 \\
\hline 400 & 39.4 & 12.9 & 3.6 & 3.3 & 0.92 & 6.7 \\
\hline 425 & 40.1 & 13.2 & 3.3 & 3.1 & 0.96 & 7.1 \\
\hline 450 & 45.2 & 15.2 & 2.2 & 2.6 & 1.21 & 9.2 \\
\hline
\end{tabular}

tem are numerous. Regardless of the fishery problem, if it deals with the dynamics of a population, the model should prove beneficial in solving it. The illustrations provided here were for common problems, but other applications such as supplementary stocking, forage-fish introductions, increased competition, seasons, habitat improvement, and the effect of powerplant impingement could be investigated.

To use the model, some time is necessary to become familiar with its requirements. Additional time is required to obtain the needed data, adjust parameters, and do preliminary trials to make the simulation perform realistically. Once this point is reached, however, countless experiments on a population can be conducted. This method can provide a substantial benefit to the efficient management of many inland fisheries. At the very least, it provides the management biologist with an educational exercise that should provide a better understanding of a fish population. The simulation can also be used strictly as an educational tool for training in population dynamics.

\section{References}

Beverton, R. J. H., and S. J. Holt. 1957. On the dynamics of exploited fish populations. Ministry of Agriculture Fish and Food (United Kingdom), Fishery Investigation Series II, Volume 19.

Brownie, D., D. R. Anderson, K. P. Burnham, and D. S. Robson. 1978. Statistical inference from band recovery data-a handbook. United States Department of Interior, United States Fish and Wildlife Service, Resource Publication 131.

Carlander, K. D. 1958. Some simple mathematical models as aids in interpreting the effect of fishing. Iowa State College Journal of Science 32:395-418.

DeAngelis, D. L., S. W. Christensen, and A. G. Clark. 1977. Responses of a fish population model to young-of-the-year mortality. Journal of the Fisheries Research Board of Canada 34:21242132.

Fox, W. W. 1970. An exponential surplus-yield model for optimizing exploited fish populations. Transactions of the American Fisheries Society 99:80-88.

Francis, R. C. 1974. Relationship of fishing mortality to natural mortality at the level of maximum sustainable yield under the logistic stock production model. Journal of the Fisheries Research Board of Canada 31:1539-1542.

Gulish, W. J. 1975. Largemouth bass harvest as a management consideration in two Indiana natural lakes. Indiana Department of Natural Resources, Indianapolis, Indiana, USA.

Gross, J. E. 1970. Program anpop: A simulation modeling exercise on the Wichita Mountains National Wildlife Refuge. Colorado Cooperative Wildlife Research Unit Progress Report, Ft. Collins, Colorado, USA.

Latta, W. C. 1971. The northern pike in Michigan: A commentary on regulations for fishing. Michigan Department of Natural Resources, Research and Development Report 241, Ann Arbor, Michigan, USA.

LATTA, W. C. 1974. Fishing regulations for largemouth bass in Michigan. Michigan Department of Natural Resources, Fishery Research Report 1818, Ann Arbor, Michigan, USA.

ORTH, D. J. 1975. Development of a computer simulation model of largemouth bass population $\mathrm{dy}$ namics. Master's Thesis, Oklahoma State University, Stillwater, Oklahoma, USA.

Patriarche, M. H. 1968. Production and theoretical equilibrium yields for the bluegill (Lepomis macrochirus) in two Michigan lakes. Transactions of the American Fisheries Society 97:242-251.

Paulik, G. J. 1969. Computer simulation models for fisheries research, management, and teaching. Transactions of the American Fisheries Society 98:551-559.

Pella, J. J., and P. K. Tomlynson. 1969. A generalized stock production model. Inter-American Tropical Tuna Commission 13:421-496. 
Pollard, R. V. 1976. A mathematical model to estimate yield for various rates of growth and mortality. Administrative Report 76-2, California Department of Fish and Game, Sacramento, California, USA.

Ricker, W. E. 1975. Computation and interpretation of biological statistics of fish populations. Fisheries Research Board of Canada Bulletin 191.

SChaEFER, M. B. 1968. Methods of estimating effects of fishing on fish populations. Transactions of the American Fisheries Society 97:231-241.

SCHNEIDER, J. C. 1973. Response of the bluegill population and fishery of Mill Lake to increased growth: a simulation model. Michigan Department of Natural Resources, Fishery Research Report 1805, Ann Arbor, Michigan, USA.

Schnute, J. 1977. Improved estimates from the Schaefer production model: theoretical considerations. Journal of the Fisheries Research Board of Canada 34:583-603.

Tadeusz, B., ANd E. D. LeCren. 1967. Some density relationships for fish population parameters. In S. D. Gerking (ed.), The biological basis of freshwater fish production. John Wiley and Sons, Inc., New York, USA.

Tautz, A., P. A. Larkin, And W. E. Ricker. 1969. Some effects of simulated long-term environmental fluctuations on maximum sustained yield. Journal of the Fisheries Research Board of Canada 26:2715-2726.

TAYLOR, M. W. 1978. A simulation model for ringnecked pheasants. Nebraska Technical Series No. 3, Nebraska Game and Parks Commission, Lincoln, Nebraska, USA.

Tester, A. L. 1953. Theoretical yields at various rates of natural and fishing mortality in stabilized fisheries. Transactions of the American Fisherie: Society 82:115-122.

Tyler, A. V. 1974. User's manual for pisces, a gen eral fish population simulator and fisheries gamt program. Technical Report 22, St. Andrews Bi ological Station, St. Andrews, New Brunswick Canada.

Walter, G. G. 1978. A surplus yield model incor porating recruitment and applied to a stock o: Atlantic mackerel (Scomber scombrus). Journal o: the Fisheries Research Board of Canada 35:229234.

Walters, C. J. 1969. A generalized computer sim ulation model for fish population studies. Trans actions of the American Fisheries Societ? 98:505-512.

Walters, C. J., R. Hilborn, E. Oguss, R. M. Peter Man, AND J. M. Stander. 1974. Development o. a simulation model of mallard duck populations Canadian Wildlife Service, Occasional Paper No 20.

WATT, K. E. F. 1956. The choice and solution o: mathematical models for predicting and maxi mizing the yield of a fishery. Journal of the Fisheries Research Board of Canada 13:613645.

Wolfert, D. R. 1969. Maturity and fecundity o: walleyes from the eastern and western basins 0 : Lake Erie. Journal of the Fisheries Researcl Board of Canada 26:1877-1888.

Youncs, W. D. 1976. An analysis of the effect $o$ : seasonal variability of harvest on the estimate $o$ : exploitation rate. Transactions of the Americar Fisheries Society 105:45-47.

Zuboy, J. R., AND R. T. LACKEy. 1975. A compute simulation model of a multi-species centrarchic population complex. Virginia Journal of Science 6:13-19. 